\title{
Proximate Composition and Mineral Contents of Freshwater Crab Spiralothelphusa hydrodroma (Herbst, 1794) from Parangipettai, South East Coast of India
}

\section{Varadharajan D* and Soundarapandian P}

Faculty of Marine Sciences, Centre of Advanced Study in Marine Biology, Annamalai University, Parangipettai-608 502, Tamil Nadu, India

\begin{abstract}
The role of aquatic rice field species in rural diets has been underestimated. These aquatic animals potentially supply most of the protein, carbohydrate and other nutrients that are needed by the villagers. The information on nutritional composition of aquatic animal resources from rice fields is scarce since they are not common in the food baskets of most other countries. Generally marine crabs are widely used as food and feed supplements throughout the world, but people do not consider paddy fields for freshwater crabs. Although large numbers of freshwater crabs are suitable for human consumption, these aquatic animals are not consumed in large quantities elsewhere. National and regional food composition data bases contain very limited info on nutritional composition of these species. In the present study an attempt has been made to evaluate the nutritional status of the edible potamid crab $S$. hydrodroma. The result showed that the parameters like protein, carbohydrate, lipid, moisture and ash and minerals of calcium, magnesium, potassium, sodium, iron, copper and zinc were maximum in cephalothorax and minimum in swimming and walking legs.
\end{abstract}

Keywords: Protein; Carbohydrate; Lipid; Minerals; S. hydrodroma; Wonderful scientific research

\section{Introduction}

The fresh water crabs is significantly an important for biological role in the food webs. More than 6,700 known species of Brachyuran crabs and over 1,300 true freshwater crabs were identified along in the world. The true freshwater crabs are fully adopted for freshwater, semi-terrestrial or terrestrial appears of life and has with the ability of characterization of complete the life cycle entirely in that region. The freshwater crabs are good source of food and medicinal values and are an important role in the food chain of aquatic ecosystems $[1,2]$. Nowadays, crabs play a significant role in the fishery wealth of many nations [3]. Mostly, the fishes, birds, caymans and mammals were resource of foods are mainly depends on the crabs $[4,5]$. There are an important protein source and are consumed in many parts of the world. Ng PKL noted that in Southern India, large potamids and parathelphusids are occasionally eaten by local peoples [4]. Yeo DCJ commented that potamids are important in the diet of rural and hill tribes of the country [6]. Freshwater crabs are also consumed for purported medicinal and tonic properties, including treatment of stomach ailments and physical injuries [7] and as food [8]. To know the nutritional value of crabs, biochemical studies are very important [9]. The nutritive value of freshwater crabs yet there is no clear cut information of the consumed peoples. Since, little work has been done in the biochemical composition of the freshwater crabs in India. The present study was undertaken to estimate the proximate composition and minerals in S. hydrodroma.

\section{Materials and Methods}

The adult crabs of S. hydrodroma were collected from the paddy fields of in and around Parangipettai. After reaching the laboratory they were washed carefully with distilled water to remove the dust and algal particles and later ice killed. The edible parts of the muscle tissues cephalothorax and the swimming and walking legs were removed with sharp forceps. The removed muscle tissues were homogenized with pestle and mortar separately. The grounded muscles were then freeze dried and powdered and eventually stored in refrigerator for further analysis. Subsequently the powdered samples were dried at $60^{\circ} \mathrm{C}$ in an oven and used for biochemical analysis. The protein, carbohydrate and lipid contents were estimated by adopting the standard methods of Raymont, Dubois, Folch J [10-12] respectively. The minerals were estimated by following the standard method of Guzman HM [13].

\section{Results and Discussion}

Crab is highly nutritious and healthy owing to its content of essential amino acids, proteins, unsaturated fatty acids, carbohydrate, fat and minerals [14-16]. Proximate composition varies with the species and is influenced by season, water temperature and spawning cycle [17]. They require for dietary importance, food texture, peptides and amino acids contribute to food flavour [18]. Protein is essential for the sustenance of life and accordingly exists in the largest quantity of all nutrients in human body [19]. An increasing demand for good quality animal protein for the exploding population has led to effective and increasing exploitation of the aquatic resources. The acceptability and easy digestibility of fish proteins make it very valuable in combating protein malnutrition, especially in children.

The results of the proximate constitutes of $S$. hydrodroma are given in Table 1. It is observed that the percentage of proximate compositions is very high in cephalothorax when compared to swimming and walking legs. The moisture content was maximum in cephalothorax

*Corresponding author: Varadharajan D, Faculty of Marine Sciences, Centre of Advanced Study in Marine Biology, Annamalai University, Parangipettai-608 502, Tamil Nadu, India, Tel: 04144-243223; Fax: 04144-243553; E-mail: heartvaradhan@gmail.com

Received December 06, 2013; Accepted December 30, 2013; Published January 07, 2014

Citation: Varadharajan D, Soundarapandian P (2014) Proximate Composition and Mineral Contents of Freshwater Crab Spiralothelphusa hydrodroma (Herbst, 1794) from Parangipettai, South East Coast of India. J Aquac Res Development 5: 217 doi:10.4172/2155-9546.1000217

Copyright: (C) 2014 Varadharajan D, et al. This is an open-access article distributed under the terms of the Creative Commons Attribution License, which permits unrestricted use, distribution, and reproduction in any medium, provided the original author and source are credited. 


\begin{tabular}{|c|c|c|}
\hline \multicolumn{3}{|c|}{ Proximate Composition (\%) } \\
\hline Protein & $13.48 \pm 2.47$ & $3.15 \pm 0.25$ \\
\hline Carbohydrate & $0.85 \pm 1.10$ & $0.34 \pm 0.10$ \\
\hline Lipid & $0.57 \pm 1.25$ & $0.19 \pm 0.28$ \\
\hline Moisture & $63.10 \pm 40.3$ & $15.21 \pm 0.40$ \\
\hline Ash & $0.72 \pm 23.19$ & $0.31 \pm 0.29$ \\
\hline \multicolumn{3}{|c|}{ Mineral Composition (\%) } \\
\hline Calcium (Ca) & $9.7 \pm 10.8$ & $4.3 \pm 1.20$ \\
\hline Magnesium (Mg) & $0.81 \pm 1.32$ & $0.36 \pm 0.15$ \\
\hline Potassium (K) & $5.20 \pm 3.45$ & $3.4 \pm 0.40$ \\
\hline Sodium (Na) & $7.51 \pm 4.10$ & $4.35 \pm 0.23$ \\
\hline Iron (Fe) & $0.014 \pm 1.13$ & $0.08 \pm 0.15$ \\
\hline Copper (Cu) & $0.02 \pm 0.52$ & $0.01 \pm 0.30$ \\
\hline Zinc (Zn) & $0.15 \pm 0.19$ & $0.8 \pm 0.14$ \\
\hline
\end{tabular}

Table 1: Showing the proximate and mineral composition of $S$. hydrodroma (Values are expressed in $\%$ on dry weight basis except moisture, Values are mean of three values $\pm \mathrm{SE})$.

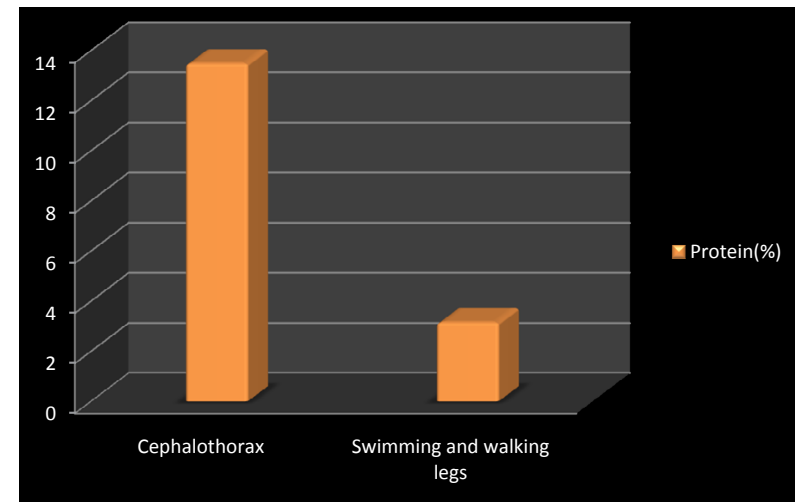

Figure 1: Protein content in the muscle tissues of cephalothorax and swimming and walking legs of $S$. hydrodroma.

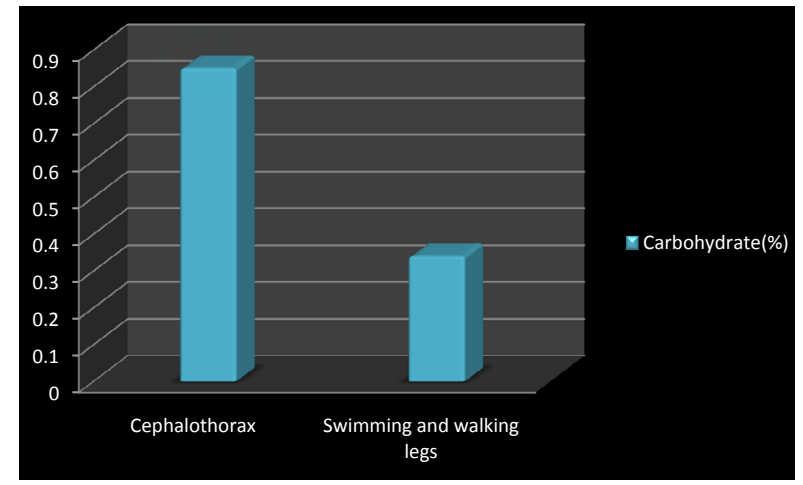

Figure 2: Carbohydrate content in the muscle tissues of cephalothorax and swimming and walking legs of $S$. hydrodroma.

$63.10 \pm 40.3$ and minimum in swimming and walking legs $3.15 \pm 0.25$ which may be advantageous in terms of the shelf life of the sample (Table 1 and Figure 5). Similar observations were also made by Akbar $Z$, Soundarapandian $\mathrm{P}[20,21]$ has been reported the moisture content of $P$. pelagicus in body meats 78.15 and claw meats-79.05, similarly the green crab C. maenus [22], blue crab C. sapidus [23]. But the moisture and ash content of the present study were somewhat higher than the values reported by Kuley E [24] in C. sapidus. The moisture ranged between $78.24-79.15 \%$ in P. sanguinolentus [25] and it varied from 74.3 to $75.44 \%$ [26].

The protein was recorded maximum in cephalothorax, $13.48 \pm 2.47$ and minimum in swimming and walking legs, $3.15 \pm 0.25$ (Table 1 and Figure 1). This is conformity with the previous studies of recorded the protein contents $P$. vigil it was recorded protein value 15.75 to $20.16 \%$ [27]; Khan PA [28] reported that the protein values in S. serrata male were $11.60 \%$ and females' for $19.92 \%$; Vasconcelos P [29] has been studied the protein content of C. affinins 17.8\%, [30] has been observed S. serrata in body meat $20.11 \%$ and claw meat $18.54 \%$; Anonymous [31] has been reported by blue crab $17.17 \%$, the protein content of $P$. pelagicus and P. sanguinolentus was 0.47 to 15.91 and 12.81 to $13.6 \%$ respectively. Radhakrishnan CK, Zafar M has been reported that the protein range in S. serrata male 17.69 and 19.39 for females [32,33]. Thirunavukkaras $\mathrm{N}$ has been observed the protein in S. tranquebarica different parts viz., body meat 65.48 to $72.24 \%$, claw meat 69.5 to $80.29 \%$ [34] and leg meat 69.47 to $74.7 \%$ [35] has been reported that the protein content in blue crab C. sapidus to be highest in the claw meat $(19.55 \mathrm{~g} / 100 \mathrm{~g})$ compared to the other parts $(18.81 \mathrm{~g} / 100 \mathrm{~g})$. Protein is the most important biochemical in crustaceans from eggs to adult and is strikingly dominant in young phases. Protein is essential for normal functions, growth and maintenance of body tissues. The crab is very often recommended for pregnant or lactating women is an excellent source of protein [14]. The ideal protein requirement for infants is $39 \%$, $26 \%$ for children and $11 \%$ for adults [36]. The crab meat will serve well in complementing cereal gruels used as weaning food for children in the tropics. Amino acids are the building blocks of proteins and serve as body builders. They are utilized to form various cell structures, of which they are key components and they serve as source of energy [37]. The carbohydrate content was significantly higher in cephalothorax $0.85 \pm 1.10$ and minimum in swimming and walking legs $0.34 \pm 0.10$ (Table 1 and Figure 2). Similar trend was already reported in different crabs viz., the range of carbohydrate was 0.3 to $0.63 \%$ in $P$. vigil [27], 2.4 to $3.4 \%$ in C. smithii [38], $0.17 \%$ in body meat and $0.24 \%$ in claw meat of S. serrata [30], 0.16 to $0.55 \%$ in P. pelagicus, 0.44 to $0.73 \%$ in $P$. sanguinolentus [32], 0.59 to $2.23 \%$ in body meat, 0.68 to $2.87 \%$ in claw meat and 0.76 to $2.76 \%$ in leg meat of $S$. tranquebarica [34].

The lipid contents were higher in cephalothorax $(0.57 \pm 1.25)$ and minimum in swimming and walking legs $0.19 \pm 0.28$ (Table 1 and Figure 3). Similar trend was already reported in different crabs viz., the range of carbohydrate was 5.13 to $9.73 \%$ in P. vigil [27], 6.2 to $7.6 \%$ in C. smithii [32], 0.7\% in C. affinis [29], 1.5\% blue crab in [31], $1.65 \%$

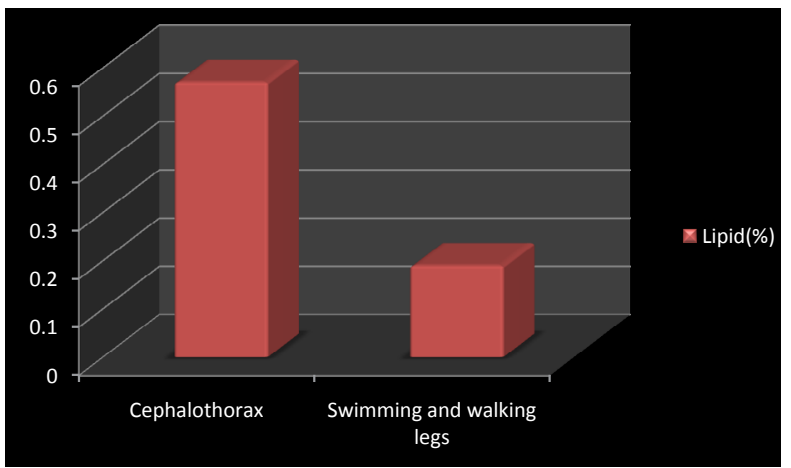

Figure 3: Lipid content in the muscle tissues of cephalothorax and swimming and walking legs of $S$. hydrodroma. 


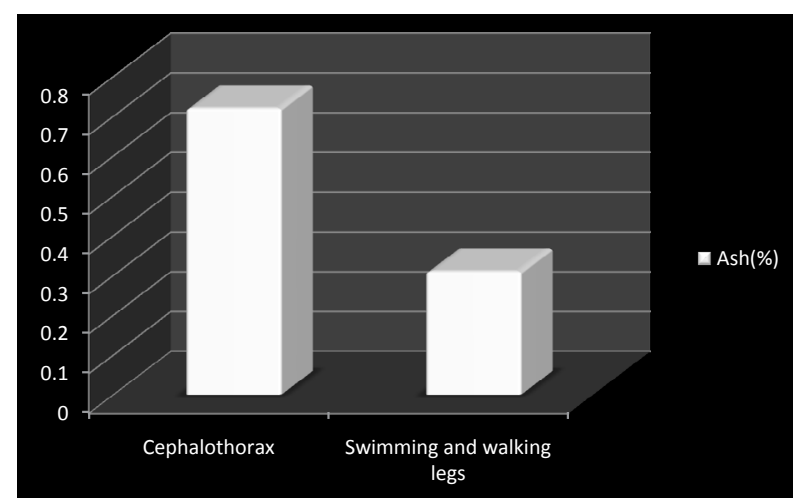

Figure 4: Ash content in the muscle tissues of cephalothorax and swimming and walking legs of $S$. hydrodroma.

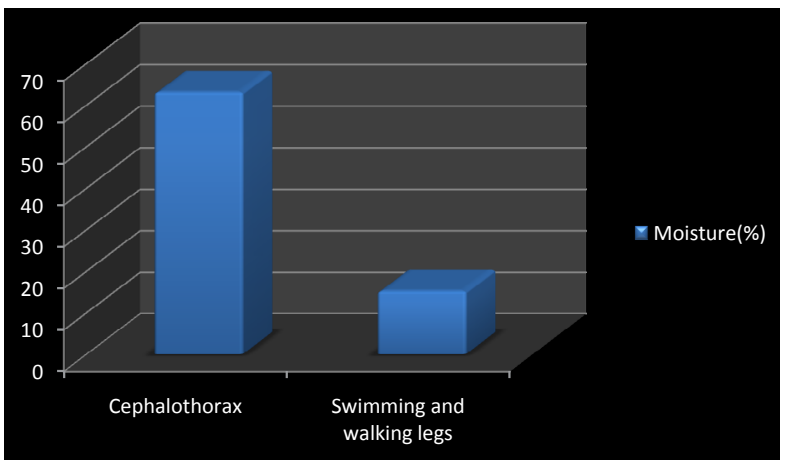

Figure 5: Moisture content in the muscle tissues of cephalothorax and swimming and walking legs of $S$. hydrodroma.

in body meat and $2.01 \%$ in claw meat of $S$. serrata [30], 3.3 to $5.6 \%$ in P. pelagicus, 3.8 to $5.5 \%$ in P. sanguinolentus [32], 0.9 to $1.6 \%$ in body meat, 1.83 to $2.06 \%$ in claw meat and 1.58 to $2.08 \%$ in leg meat of S. tranquebarica [34]. $0.43 \%$ in egg, $0.7 \%$ in without egg, $1.07 \%$, in body meat and $1.0 \%$ in claw meat of S. serrata [39]. In crustaceans, lipids are not only the main organic reserve and source of metabolic energy but also indispensable in maintaining cellular integrity. Lipids as a general rule act as major food reserve along with protein and are subject to periodic fluctuation influenced by environmental variable like temperature [40]. Ash content was maximum in cephalothorax $(0.72 \pm 23.19)$ and minimum in swimming and walking legs $(0.31 \pm 0.29)$ (Table 1 and Figure 4). Similar trend was already reported in different crabs viz., [41] has been studied in Edible Crab, Podophthalmus vigil, [22] has been studied in green crab C. maenus, [30] has been studied in S. serrata, [15] has been studied in blue crab, [42] has been studied in green and blue crab, 17-19\% in $S$. tranquebarica [26], 7.62 to $7.83 \%$ in P. sanguinolentus[25].

The results of the various minerals compositions of $S$. hydrodroma are shown in Table 1. It is also observed that the percentage of mineral compositions is very high in ephalothorax when compared to swimming and walking legs. The calcium (ca) recorded was maximum in cephalothorax 9.7 \pm 10.8 and minimum in swimming and walking legs $4.3 \pm 1.20$ (Table 1 and Figure 6). Earlier report agreed with this study where $2157.86 \pm 1.01 \mathrm{mg} / 100 \mathrm{~g}$ of calcium was recorded in land crab C. armatum [43], $15.670 \mathrm{mg} / \mathrm{gm}$ in $P$. vigil [25] and Chinese mitten crab and $0.67 \mathrm{mg} / \mathrm{gm}$ in E. sinesis [44].
Magnesium (mg) recorded was maximum in cephalothorax 0.81 \pm 1.32 and minimum in swimming and walking legs, $0.36 \pm 0.15$ (Table 1 and Figure 7). In the previous studies made, Magnesium (mg) was recorded to be $0.39 \pm 0.01$ in in land crab C. armatum [43], $0.212 \mathrm{mg} / \mathrm{gm}$ in P.vigil [25] and $0.22 \mathrm{mg} / \mathrm{gm}$ in Chinese mitten crab E. sinesis [44]. Potassium $(\mathrm{K})$ was recorded maximum in cephalothorax $5.20 \pm 3.45$ and minimum was recorded in swimming and walking legs $3.4 \pm 0.40$ (Table 1 and Figure 8). In earlier studies, $367.19 \pm 0.01 \mathrm{mg} / 100 \mathrm{~g}$ of Patassium was recorded in land crab C. armatum [43], $4.780 \mathrm{mg} / \mathrm{gm}$ in P. vigil [25] and $2.73 \mathrm{mg} / \mathrm{gm}$ in Chinese mitten crab E. sinesis [44]. Sodium $(\mathrm{Na})$ recorded was maximum in cephalothorax $7.51 \pm 4.10$ and minimum was recorded in swimming and walking legs $4.35 \pm 0.23$ (Table 1 and Figure 9). In earlier studies, $297.80 \pm 0.01 \mathrm{mg} / \mathrm{gm}$ of sodium $(\mathrm{Na})$ was recorded in land crab C. armatum [43], $3.010 \mathrm{mg} / \mathrm{gm}$ in P. vigil [25], $1.90 \mathrm{mg} /$ gm in Chinese mitten crab E. sinesis [44]. Iron (Fe) was recorded maximum in cephalothorax $0.014 \pm 1.13$ and minimum was recorded in swimming and walking legs $0.08 \pm 0.15$ (Table 1 and Figure 10). In earlier studies, $27 \pm 95.10 \mathrm{mg} / 100 \mathrm{~g}$ of iron $(\mathrm{Fe})$ was recorded in land crab C. armatum [43], $3.3570 \mathrm{mg} / \mathrm{gm}$ in $P$. vigil [25], $0.039 \mathrm{mg} /$ $\mathrm{gm}$ in Chinese mitten crab E. sinesis [44]. Copper $(\mathrm{Cu})$ recorded was maximum in cephalothorax $0.02 \pm 0.52$ and minimum was recorded in swimming and walking legs $0.01 \pm 0.30$ (Table 1 and Figure 11). In earlier studies, $57.83 \pm 0.10 \mathrm{mg} / 100 \mathrm{~g}$ of copper $(\mathrm{Cu})$ was recorded in land crab C. armatum [43], $0.450 \mathrm{mg} / \mathrm{gm}$ in P.vigil [25], $0.16 \mathrm{mg} /$ gm in Chinese mitten crab E. sinesis [44]. Zinc (Zn) recorded was maximum in cephalothorax $0.15 \pm 0.19$ and minimum was recorded in swimming and walking legs $0.8 \pm 0.14$ respectively (Table 1 and Figure

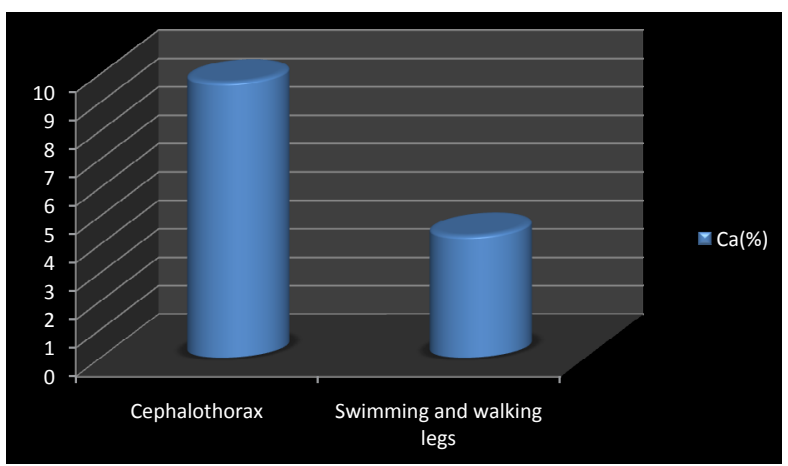

Figure 6: Calcium content in the muscle tissues of cephalothorax and swimming and walking legs of $S$. hydrodroma.

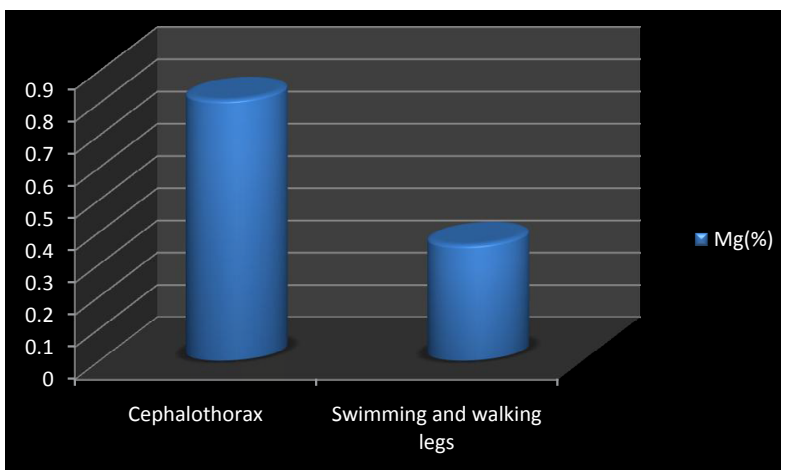

Figure 7: Magnesium content in the muscle tissues of cephalothorax and swimming and walking legs of $S$. hydrodroma. 


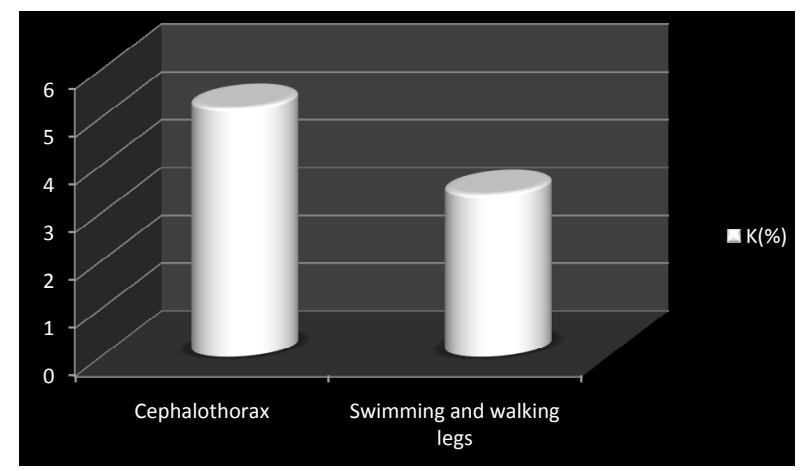

Figure 8: Potassium content in the muscle tissues of cephalothorax and swimming and walking legs of $S$. hydrodroma.

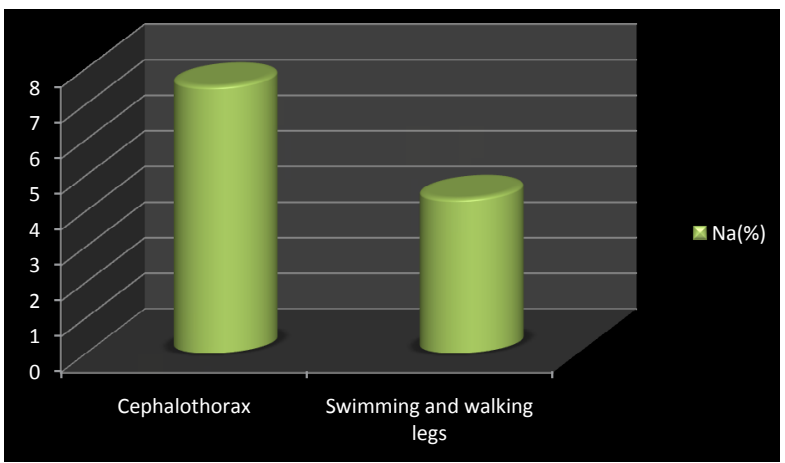

Figure 9: Sodium content in the muscle tissues of cephalothorax and swimming and walking legs of $S$. hydrodroma.

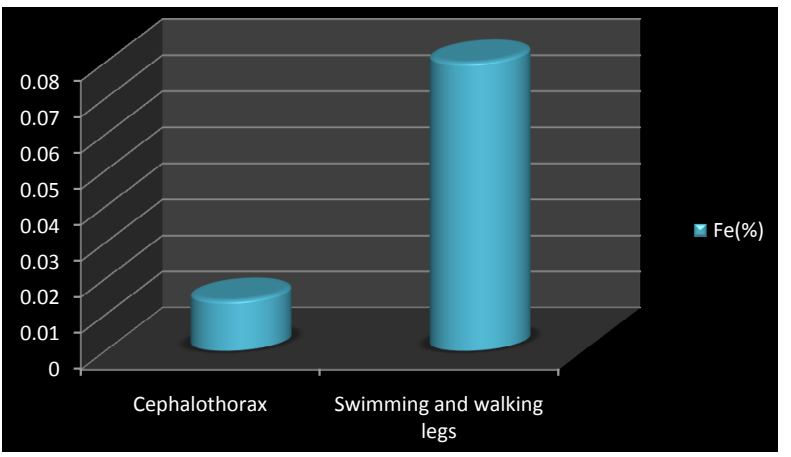

Figure 10: Iron content in the muscle tissues of cephalothorax and swimming and walking legs of $S$. hydrodroma.

12). In earlier studies, $15.23 \pm 0.11 \mathrm{mg} / 100 \mathrm{~g}$ zinc $(\mathrm{Zn})$ was recorded in land crab C. armatum [43], $1.565 \mathrm{mg} / \mathrm{gm}$ in P. vigil [25], 0.091 $\mathrm{mg} / \mathrm{gm}$ in Chinese mitten crab E. sinesis [44]. Similar observations made by [14] investigated the mineral content of freshwater crab S. africanus africanus. [45] has recorded nine minerals (Ca $115 \pm 13$ $\mu \mathrm{g} \mathrm{g} 1$, K $9916 \pm 467 \mu \mathrm{g} \mathrm{g}^{-1}$, Fe $191 \pm 18 \mu \mathrm{g} \mathrm{g}{ }^{-1}, \mathrm{Cu} 157 \pm 10 \mu \mathrm{g} \mathrm{g}{ }^{-1}, \mathrm{Mn}$ $10.3 \pm 1.2 \mu \mathrm{g} \mathrm{g}^{-1}, \mathrm{Zn} 130 \pm 1 \mu \mathrm{g} \mathrm{g}^{-1}$, Se, $0.71 \pm 0.05 \mu \mathrm{g} \mathrm{g}^{-1}$, Br $10.1 \pm 1.1$ $\left.\mu \mathrm{g} \mathrm{g}^{-1}, \mathrm{~Pb} 0.128 \pm 0.003 \mu \mathrm{g} \mathrm{g}^{-1}\right)$ from different tissues of $S$. serrata and [46] has reported the concentration of 10 elements in (ppm)in different crustaceans viz., S. tranquebarica (K, $8040 \pm 340$, Ca $2846 \pm 12, \mathrm{Mn}$ $11.2 \pm 2.5$, Fe $156 \pm 6$, Cu $121 \pm 12$, Zn $270 \pm 36$, Se $0.40 \pm 0.10$, Br 295 \pm 23 , Sr $13.5 \pm 1.3$ and $\mathrm{Pb} 0.201 \pm 0.08)$ and $P$. monodon (K $9095 \pm 342$, Ca $665 \pm$ 19, Mn $15.2 \pm 3.3$, Fe $297 \pm 8$, Cu $77 \pm 11$, Zn $58 \pm 21$, Se 0.33 $\pm 0.14, \mathrm{Br} 27 \pm 6, \mathrm{Sr} 2.55 \pm 1.3$ and $\mathrm{Pb} 0.147 \pm 0.10$ and in $P$. indicus (K $8695 \pm 250$, Ca $824 \pm 17$, Mn $11.8 \pm 2.4$, Fe $107 \pm 4$, Cu $70 \pm 8$, Zn $54 \pm$ 15 , Se $0.37 \pm 0.10, \mathrm{Br} 19 \pm 5$, Sr $2.52 \pm 1.2$ and Pb $0.352 \pm 0.10$ ), Salaenoi $\mathrm{J}$ [47] has reported the trace elements content in haemolymph and red sternum of mud crab (Calcium 342.15, Magnesium 252.68, Iron 2.46, Chloride 715, Copper 122.55, Manganese 6.76 and Zinc 23.76) and (Calcium 372.90, Magnesium 400.95, Iron 10.80, Chloride 728, Copper 37.44, Manganese 3.44 and Zinc 5.78). Moronkolaa BA [48] reported that the mineral contents of Crab C. amnicola in different parts.

Biochemical changes in the gonads, digestive gland and muscle during maturation, molting and reproduction have been examined in many species of decapods crustaceans [49,50,51]. The biochemistry of reproduction has been fairly well studied in S. hydroroma, this work is comprehensive and include studies relating to neurosecretory control of reproduction and moulting, protein metabolism in relation of both processes, as well as mobilization of organic resources, lipids and free sugars. In the present study, the people do not consider the edible part of legs, there are discarded and are rarely eaten. Legs contains are significant amount of nutrients, therefore yet there no clear cut information of the leg meats nutrient values. In recent days many seafood restaurants typically boil the legs and serve them with condiments such as butter and lemon juice. Since the crab $S$. hydrodroma legs are good source of protein and mineral, it can be used as a well selection of food for human consumption. In the study also recommended that the taken due to crab legs can contribute to a healthy diet. They are high in protein, carbohydrate, lipid and minerals.

Generally the crabs claw like dactyl, a Y-shaped walking leg and a fork-shaped walking leg might represent different degrees of

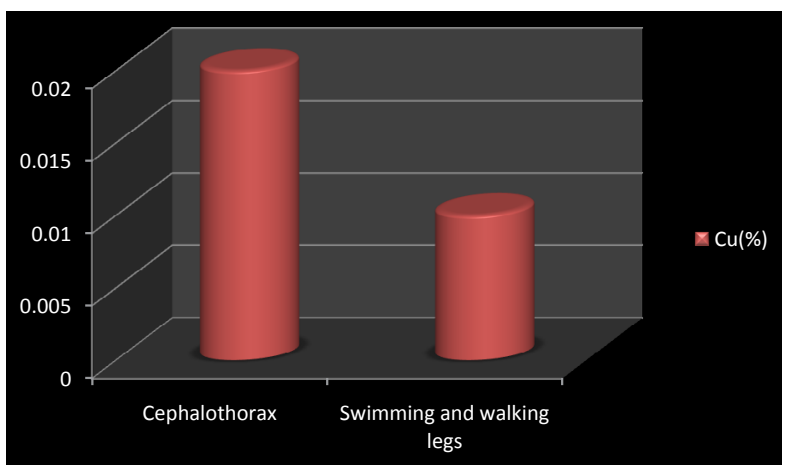

Figure 11: Copper content in the muscle tissues of cephalothorax and swimming and walking legs of S. hydrodroma.

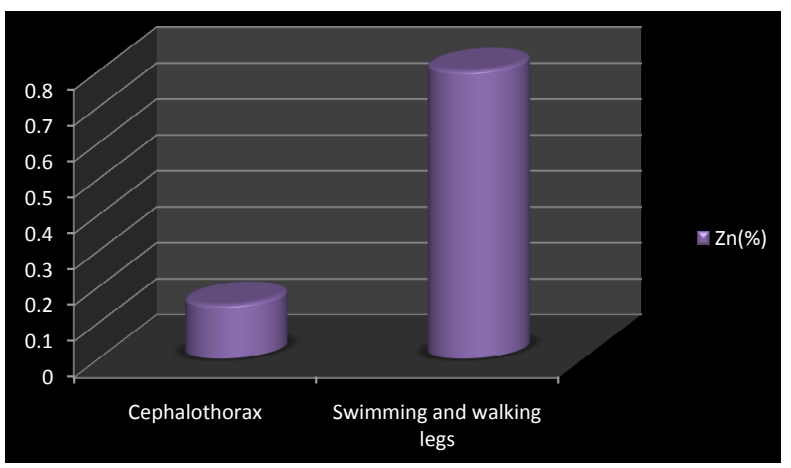

Figure 12: Zinc content in the muscle tissues of cephalothorax and swimming and walking legs of $S$. hydrodroma. 
Citation: Varadharajan D, Soundarapandian P (2014) Proximate Composition and Mineral Contents of Freshwater Crab Spiralothelphusa hydrodroma (Herbst, 1794) from Parangipettai, South East Coast of India. J Aquac Res Development 5: 217 doi:10.4172/2155-9546.1000217

Page 5 of 6

claw transformation $[13,14,21]$. The study indicates that the ratio of carbohydrate was less when compared to the other nutrients such as proteins and lipids in animal tissues, especially in aquatic animals [25, 27]. The previous studies suggested that the carbohydrate in the muscle tissues varied in S. serrata [30]. Carbohydrates constitute only a minor percentage of total biochemical composition. They also contain traces of glucose, fructose, sucrose and other mono and disaccharides [24,28]. Carbohydrates provide the body with fuel and energy to keep going throughout the day and should make up half the daily intake of food. Carbohydrates are also important for the correct working of human brain, heart and nervous, digestive and immune systems.

Nutrients are required in order to build and repair cells and body tissues, maintain the organs and bones in optimum working condition and to provide energy, fuel and warmth. Good nutrition is essential for good health and eating nutritious food can help prevent common ailments, as well as more life threatening illnesses and diseases. Crabs have 71 to 85 calories and no dietary fiber or carbohydrates. They provide $15 \mathrm{~g}$ of high-quality protein, which represents 30 percent of the recommended daily value based on a 2,000-calorie a day diet. The present study considered the claw meat because $100 \mathrm{~g}$ claw meat of the blue crab consists of $1309 \mathrm{mg}$ leucine and $941 \mathrm{mg}$ isoleucine and assuming an adult human consumes $50 \mathrm{~g}$ blue crab, this can provide the daily amino acid requirement [36]. The aquatic resources make up the majority of animal protein consumed in terms of frequency and quantity $[5,8,10]$. Rice based aquatic ecosystems have a high biodiversity and are a rich source of nutrient dense local food $[4,6,9]$. This study documented that daily consumed aquatic animal especially crab is a good source of cheap animal protein, which is either eaten as snacks and as part of main meals by people of the country.

\section{References}

1. Cobb BF, Conte FS, Edwards MA (1975) Free Amino Acids and Osmoregulation in Penaeid Shrimp. J Agric Food Chem 23: 1172-1174.

2. Fang LS, Tang CK, Lee DL, Chen IM (1992) Free Amino Acid Composition in Muscle and Hemolymph of the Prawn Penaeus Monodon in Different Salinities. Nippon Suisan Gakkaishi. 58: 1095-1102.

3. Chhapgar BF (1991) Seashore Life of India. Nature Guides, Oxford University Press, Bombay India. 18-24.

4. Ng PKL (1988) The Freshwater Crabs of Peninsular Malaysia and Singapore; Singapore (Shinglee).

5. Magalhaes C (2003) Familias Pseudothelphusidae E Trichodactylidae, In GAS Melo (Org.) Manual De Identificacao Dos Crustacea Decapoda De Agua Doce Do Brasil. Edicoes Loyola, Sao Paulo, SP Brazil. 143-287.

6. Yeo DCJ, Ng PKL (1998) Nomenclatural Notes on Hainanpotamon (Dai, 1995) (Brachyura, Potamidae), Orientalia Dang, 1975 (Brachyura, Potamidae) and Orientalia Radoman, 1972 (Molᄀlusca, Gastropoda, Prosobranchia, Hydrobiidae). Crusta 71: 357-359.

7. Dai AY (1999) Fauna Sinica. Arthropoda: Crustacea: Malacostraca: Decapoda: Parathelphusidae, Potamidae. Beijing. Sci Press 501: 30.

8. Finkers J (1986) Los Yanomami Y Su Sistema Alimenticio. Vicariato Apostolico De Puerto Ayacucho, Puerto Ayacucho. Monografia 2: 262

9. Soundarapandian P, Dinakaran GK, Mrinmoy Ghosh (2010) Effect of Diets on the Biochemical Changes of Fattened Commercially Important Crab Portunus Sanguinolentus (Herbst). Curr Res J Biol Sci 2: 107-113.

10. Raymont JEG, Austin J, Linford E (1964) Biochemical Studies on Marine Zooplankton. I. The Biochemical Composition of Neomysis Integer. J Cons Perm Explor Mar 28: 354-363.

11. Dubois M, Giles KA, Hamilton JK, Rebors PA, Smith F (1956) Calorimetric Method for Determination of Sugar and Related Substances. Analyt J Biol Chem 28: 350-356

12. Folch J, Lees M, Sloane GSH (1957) A Simple Method for the Isolation and Purification of Total Lipids from Animal Tissue. J Biol Chem 226: 497-509.
13. Guzman HM, Jimenez CE (1992) Concentration of Coral Reefs By Heavy Metals along the Carribean Cost of Central Africa (Costarica And Panama). Mar Poll Bull 24: 554-561.

14. Adeyeye El (2002) Determination of the Chemical Composition of the Nutritionally Valuable Parts of Male and Female Common West African Fresh Water Crab Sudananautes Africanus Africanus. Int J Food Sci Nut 53: 189-196.

15. Celik M, Tureli C, Celik M, Yanar Y, Erdem U, Kucukgulmez A (2004) Fatty Acid Composition of The Blue Crab (Callinectes Sapidus) in The North Eastern Mediterranean. Food Chem 88: 271-273.

16. Musaiger AO, Al-Rumaidh MJ (2005) Proximate and Mineral Composition of Crab Meat Consumed in Bahrain. Int J Food Sci Nutr 56: 231-5.

17. Ockerman HW (1992) Fishery By-Products, In: Hall GM, Editor. Fish Processing Technology.155-92. Chapman and Hall: New York.

18. Cruz-Garcia CDL, Lepez-Hernandez J, Gonzalez-Castro MJ, De Quires ARB Simal-Lozano J (2000) Protein, Amino Acid and Fatty Acid Contents in Raw and Canned Sea Urchin (Paracentrotus Lividus) Harvested in Galicia. J Sci Food Agric 80: 1189-1192.

19. Okuzumi M, Fujii T (2000) Nutritional and Functional Properties of Squid and Cuttle Fish. 35th Anniversary of Commemorative Publication. 223.

20. Akbar Z, Qasim R, Siddiqui PJA (1988) Seasonal Variations in Biochemical Composition Of Edible Crab (Portunus Pelagicus Linnaeus). J Islam Acad Sci 1: 127-133.

21. Soundarapandian P, Singh RK (2008) Biochemical Composition of the Eggs of Commercially Important Crab Portunus Pelagicus (Linnaeus). Inter J Zoo Res 4:53-58.

22. Skonberg DI, Perkins BL (2002) Nutrient Composition of Green Crab (Carcinus Maenus) Leg Meat and Claw Meat. Food Chem 77: 401-404.

23. Kucukgulmez A, Celik M, Yanar Y, Ersoy B, Cikrikci M (2006) Proximate Composition and Mineral Contents of The Blue Crab (Callinectes Sapidus) Breast Meat, Claw Meat And Hepatopancreas. Int J Food Sci Technol 41: 1023-1026.

24. Kuley E, Ozogul F, Ozogul Y, Olgunoglu Al (2007) Comparison of Fatty Acid and Compositions of the Body and Claw of Male and Female Blue Crabs (Callinectes Sapidus) from Different Regions of The Mediterranean Coast. Int J Food Sci Nut 12: 541-560.

25. Sudhakar M, Raja K, Anathan G, Sampath Kumar P (2011) Compositiona Characteristics and Nutritional Quality of Podopthalamus Vigil (Fabricius) Asian J Biol Sci 4:166 - 174.

26. Manivannan K, Sudhakar M, Murugesan R, Soundarapandian P (2010) Effect of Feed on The Biochemical Composition of Commercially Important Mud Crab Scylla Tranquebarica (Fabricius 1798). Inter J Ani Veter Advan 2: 16-20.

27. Radhakrishnan CK, Natarajan R (1979) Nutritive Value of the Crab Podopthalamus Vigil (Fabricius). Fish Technol 16: 37 - 38.

28. Khan PA (1992) Biochemical Composition, Minerals (Calcium And Iron) And Chitin Content of Two Portunid Crabs Scylla Serrata, Forskal and Portunus Pelagicus Linnaeus Available in And Around The Coastal Region Of Bangladesh, M.Sc. Thesis, Institute of Marine Science, Chittagong University. 112

29. Vasconcelos P, Braz NR (2001) Proximate Composition of The Deep Sea Crab, Chaceon Affinis From An Exploratory Fishery of Maderia Island (Portuga - Eastern Central Atlantic) North West Atlantic Fisheries Organisation. 1 - 6.

30. Prasad PN, Neelakantan B (1989) Proximate and Essential Amino Acid Composition in Edible Crab Scylla Serrata. Comp Physiol Ecol 14: 34-37.

31. Anonymous (1999) Results From The USDA, Nutrient Database For Standard Reference Crustaceans. Crab Blue, Cooked, Moist Head. Blue Crab-Nutrition Html.1-3.

32. Radhakrishnan CK (2000) The Eggs of Marine Crabs-An Unexploited Resource. ICLARM Quart 23: 4-5.

33. Zafar M, Siddiqui MZH, Hoque MA (2004) Biochemical Composition in Scylla Serrata (Forskal) Of Chakaria, Sundarban Area, Bangladesh. Pak J Biol Sci 7: 2182-2186.

34. Thirunavukkaras N (2005) Biology, Nutritional Evaluation and Utilization Of Mud Crab Scylla Tranquebarica (Fabricius, 1798). Ph.D. Thesis. Annamalai University, India. 
Citation: Varadharajan D, Soundarapandian P (2014) Proximate Composition and Mineral Contents of Freshwater Crab Spiralothelphusa hydrodroma (Herbst, 1794) from Parangipettai, South East Coast of India. J Aquac Res Development 5: 217 doi:10.4172/2155-9546.1000217

35. Aygul Kucukgulmez, Mehmet Celik, Yasemen Yanar, Beyza Ersoy, Mustafa C, Ikrikc I (2006) Proximate Composition And Mineral Contents of The Blue Crab (Callinectes Sapidus) Breast Meat, Claw Meat And Hepatopancreas. Inter J Food Sci Technol 41: 1023-1026 1023

36. FAO/WHO/UNU (1985) Energy and Protein Requirements. Who Technical Report Series No. 724. WHO, Geneva, Switzerland.13-205.

37. Babsky EB, Khodorov BI, Kositsky GI, Zubkov AA (1989) In Babsky, E.B. (Ed), Human Physiology, Mir Publishers, Moscow.

38. Balasubramanian CP, Suseelan C (2001) Biochemical Composition of the Deep Water Crab Charybdis Smithii. Indian J Fish 48: 333-335.

39. George C, Gopakumar K (1987) Biochemical Studies on Crab Scylla Serrata. Fish Tech 24: 57-61.

40. Johnston J (1917) The Dietic Value of Hearing. Rep. Laucas Sea Fish Lab 32-85.

41. Soundarapandian P, Ravichandran S, Varadharajan D (2013) Biochemical Composition of Edible Crab, Podophthalmus Vigil (Fabricius). J Marine Sci Res Dev 3: 119.

42. Naczk M, Williams J, Brennan K, Liyanapathirana C, Shahidi F (2004) Compositional Characteristics of Green Crab (Carcinus Maenas). Food Chem 88: 429-434

43. Omotoso OT (2005) Chemical Composition and Nutritive Significances of the Land Crab Cardisoma Armatum. African J Appl Zoo Environ Biol 7:68-72.
44. Chen D, Zhang W, Shrestha MS (2007) Compositional Characteristics and Nutritional Quality of Chinese Mitten Crab (Eriocheir Sinesis). Food Chem 10: 1343 - 1349.

45. Mohapatra A, Rautray RT, Patra AK, Vijayan V, Mohanty RK (2009) Elemental Composition in Mud Crab Scylla Serrata from Mahanadi Estuary, India: In Situ Irradiation Analysis by External PIXE. Food Chem Toxicol 47: 119-123.

46. Mohapatra A, Rautray TR, Vijayan V, Mohanty RK, Dey SK (2007) Trace Elemental Characterization of Some Food Crustacean Tissue Samples By EDXRF Technique. Aquacult 270: 552-558.

47. Salaenoi J, Sangcharoen A, Thongpan A, Mingmuang M (2006) Morphology and Haemolymph Composition Changes in Red Sternum Mud Crab (Scylla Serrata) Kasetsart. J Nat Sci 40: 158-166.

48. Moronkolaa BA, Olowu RA, Tovidea OO, Ayejuyob OO (2011) Determination of Proximate and Mineral Contents of Crab (Callinectes Amnicola) Living on The Shore of Ojo River, Lagos, Nigeria. Sci Revs Chem Commun 1: 1-6.

49. Gehring WR (1974) Maturational Changes in The Ovarian Lipid Spectrum of The Pink Shrimp, Penaeus Duorarum Duorarum Burkenroad. Comp Biochem Physiol 49: 511-524.

50. Read GH, Caulton MS (1980) Changes in Mass and Chemical Composition During the Moult Cycle and Ovarian Development in Immature and Mature Penaeus Indicus Milne Edwards. Comp Biochem Physiol 66: 431-437.

51. Hask BE, Felder DL (2005) Biochemical Composition of Ovary, Embryo and Hepatopancreas in Grapsoid Crabs Armases Cinerum and Sesarma Nr. Reticulatum. Comp Biochem Physiol 140: 455-463. 